Матеріали Всеукраїнської науково-практичної конференчії «Актуальні питання діагностики, лікування, раціональної фармакотерапії, диспансеризації та реабілітації в практиці сімейного лікаря»

УДК 616.711-018.3-002-08.814.1-06:616.71-007.234

DOI

\title{
ЕФЕКТИВНІСТЬ КОМПЛЕКСНОГО ЛІКУВАННЯ ХВОРИХ З ПОПЕРЕКОВИМ ОСТЕОХОНДРОЗОМ ЗА ДИНАМІКОЮ СТАНУ ЕНДОТЕЛІАЛЬНОЇ ДИСФУНКЦІї
}

\author{
๑Л. С. Бабінець ${ }^{1}$, А. Л. Надкевич ${ }^{2}$, І. В. Готь ${ }^{3}$
}

ДВНЗ «Тернопільський державний медичний університет імені І. Я. Горбачевського МОЗ України»' КУтОР «Микулинецька обласна фізіотерапевтична лікарня реабілітації»

ЛОР «Львівський інститут медсестринства та лабораторної діагностики імені А. Крупинського»

На сьогодні не вирішені численні питання етіопатогенезу, діагностики та лікування поперекового остеохондрозу (ПОХ). Зокрема, роль системи оксиду азоту (NO) у розвитку і прогресуванні ПОХ та остеодефіциту (ОД) залишається недостатньо з'ясованою.

Мета дослідження - проаналізувати динаміку вмісту стабільних метаболітів NO у хворих 3 рефлекторними проявами ПОХ із супутнім ОД під впливом комплексного лікування з включенням курсу традиційного внутрішньом'язового та акупунктурного введення мелоксикаму.

Матеріали та методи дослідження. Було обстежено 46 хворих з рефлекторними проявами ПОХ на тлі ОД, які лікувались в амбулаторних умовах. Кількісно больовий синдром (БС) різної інтенсивності у поперековому відділі хребта оцінювали за кількістю хворих з БС, вираженою у \%. Синдром ендотеліальної дисфункції (ЕД) вивчали за рівнем метаболіту $\mathrm{NO}_{2}$, який визначали за методом Гріна за допомогою реактива Гріса. Група контролю склала 20 практично здорових людей. Усі розрахунки виконано за допомогою програмного забезпечення Mathcad 14. Для оцінки достовірності відмінностей середніх значень у вибірках використовували двовибірковий t-критерій Стьюдента.

Пацієнти з ПОХ на тлі ОД були поділені на 2 групи. I група (25 хворих) отримувала загальноприйняте лікування (ЗЛ). II група пацієнтів (21 хворий) - ЗЛ із курсом фармакопунктури (ФП) мелоксикаму № 5. У ході лікування використовували точки акупунктури попереково-крижового відділу хребта та сідниць, де анатомічно достатньо виражений м'язовий шар для безпеки проведення ФП: V21-25, V50-54, V27-29, V36-40, V55-57. Моваліс вводили по 1 ампулі на сеанс 1,5 мл (по 0,2-0,3 мл у кожну точку за допомогою інсулінового шприца) впродовж 5 днів. Програма корекції II групи хворих на ПОХ відрізнялась від такої у I групі тільки шляхом введення препарату. Побічних ефектів і технічних проблем при проведенні ФП мовалісу не було. Пацієнти позитивно ставились до проведення процедур, відмічали швидкий клінічний, насамперед знеболювальний ефект.

Результати та їх обговорення. Було визначено динаміку БС у хворих на ПОХ із супутнім ОД до (був наявним у 100,0 \% пацієнтів I і II груп) і після проведеного лікування (вважали БС наявним за відсутності значимої позитивної динаміки): I - 26,3 \%; II - 6,7 \%. Це засвідчило більш значиму позитивну динаміку елімінації БС при ПОХ при включенні до ЗЛ курсу ФП мелоксикаму, порівняно з групою $3 Л$.

При ПОХ було встановлено посилення явищ ЕД (за рівнем метаболіту $\mathrm{NO}_{2}$ ). Порівняльний аналіз впливу лікувальних програм констатував, що якщо курсове традиційне застосування мелоксикаму у комплексному лікуванні хворих на ПОХ на тлі ОД призводило до зниження ЕД (за рівнем метаболіту $\left.\mathrm{NO}_{2}\right)$ з $(4,90 \pm 0,03)$ до $(4,30 \pm 0,04)$ мкмоль/л $(p>0,05)$ при показнику у групі контролю $(3,82 \pm 0,09)$ мкмоль/л, то ФП мелоксикаму призводила до більш значимого ефекту зниження ЕД з $(5,1 \pm 0,02)$ до $(3,8 \pm 0,05)$ мкмоль/л $(p<0,05)$, що засвідчило високу протизапальну ефективність мелоксикаму взагалі і доцільність введення його у точки акупунктури за запропонованою методикою.

Висновок. Застосування фармакопунктури мелоксикаму в комплексному лікуванні хворих на ПОХ на тлі ОД призводило до більш значимого зниження (за рівнем метаболіту $\mathrm{NO}_{2}$ ) ендотеліальної дисфункції з $(5,1 \pm 0,02)$ до $(3,8 \pm 0,05)$ мкмоль/л) $(p<0,05)$, що засвідчило високу протизапальну ефективність мелоксикаму взагалі і доцільність введення його у точки акупунктури за запропонованою методикою.

Перспектива подальших досліджень: аналіз ефективності запропонованих лікувальних програм з рефлекторними методиками за динамікою цитокінового та антиоксидантного статусу хворих на ПОХ з ОД. 